\title{
Critical View on The Existence of Gambus Tunggal Lampung: Promoting Collaborative Working Between Artists and Stakeholders
}

\author{
Prisma Tejapermana ${ }^{\bowtie}$, Riyan Hidayatullah
}

Universitas Lampung, Indonesia

Submitted: June 28, 2020. Revised: September 9, 2020. Accepted: November 14, 2020

\begin{abstract}
The Lampung societies have many arts and cultures, one of which is a gambus tunggal. The characteristic of gambus that are played solely and has an original tuning system. A gambus tunggal style produces a melodic tone, accompanied by chanted poems that involve new romantic romance of Lampung, or parents' advice to their children. This ethnography study aims to comprehend how the gambus tunggal artists maintain the existence in Lampung. The study applies a descriptive method with a qualitative idea. We have interrogated and field studies to gather primary data. A purposive sampling technique was used to interview a gambus tunggal player who existed for decades. The result indicates that a gambus tunggal artist is doing a collaborative struggle to support gambus tunggal and living sources' survival. They need collaboration to keep the existence of traditional Lampung music. Gambus players have considered using social media as a promotional strategy. The local government's role has a tremendous impact, for example, providing an opportunity to perform gambus tunggal at various events, festivals, and many competitions. Therefore, the tourism sector is the foundation of Lampung's traditional music. It establishes policies to serve various performing arts.
\end{abstract}

Keywords: gambus tunggal; Lampung culture; traditional music

How to Cite: Tejapermana, P., \& Hidayatullah, R. (2020). Critical View on The Existence of Gambus Tunggal Lampung: Promoting Collaborative Working Between Artists and Stakeholders. Harmonia: Journal of Arts Research And Education, 20(2), 176-182

\section{INTRODUCTION}

The local art is a cultural product, and culture arises from society's habit; good art can also determine a culture's sustainability. This opinion follows the statement of Koentjaraningrat (2009) that the value of culture is the highest and most abstract of the customs. Therefore cultural values consist of a conception of everything valued and essential by society so that the belief can serve as a guideline in the living source. Geertz suggests that culture is a historically forwarded pattern of meaning that materialize in symbolic forms. Culture is a system of concepts inherited in symbolic forms by which humans communicate, preserve, and develop the knowledge of life and attitudes toward life (Sumardjo, 2009).

Indonesia consists of various arts and cultures. One of the traditional arts areas is Lampung such as bedana dance, the cangget agung dance, sekura, gamolan, talo balak, gambus tunggal (petting gambus), serdam (Lampung's flute), ghujih and many more.

\footnotetext{
Corresponding author:

E-mail: prisma.tejapermana@fkip.unila.ac.id
} 
The traditional arts from the branch of music, Lampung has a wide variety of music, as for the type of music that still survive until now is the gambus tunggal Kalianda. This type of music is usually accompanied by a gambus instrument (petting gambus) by singing verses about advice, expressions of love during ngiban/nganjang, and ngababang to spoil the couple. Gambus tunggal is a musical art that spreads almost all corners of Sumatera's island, but there are differences in some areas that use guitars in their performances. As the name suggests, this art characteristic is a skill gambus played by himself, with the syair-syair of most pantun-shaped. The art of the gambus tunggal usually played by the young people who are chatting or parents who are giving a discourse to children or youth. This art used to be very desirable and famous, no undo of the music experts in playing the gambus tunggal and famous almost in the whole of Sumatera, especially the southern part, Riau, Jambi, Bengkulu, and Lampung.

The indigenous people of Lampung hold a living philosophy called piil pesenggiri. These contain principles and values about maintaining self- esteem (Sinaga 2012). Piil pesenggiri is representation some positive values, including: (1) nemui nyimah as a form of kinship; (2) nengah nyappur as a form of society that loves to mingle and assemble; (3) sakai sambayan as a representation of the community who likes each other; (4) juluk adek as an attempt to retain identity (Hadikusuma, 1990).

Gambus tunggal is an acculturation of Arabic culture. The tones used are monophonic, meaning that it is not based on the composition of their counterparts or harmony. While the scale used maqam (plural: maqamat), the arrangement of tones is not tuned perfect (well-tempered) as well as western music. Nevertheless, if it is harmonized with Western music's scale/ scale, it refers more to the harmonic minor scale.

Minor taste is felt in these gambus tunggal vibes. The verses are in the form of segata or rhymes whose contents are interrelated from the first and last ones. The contents of poem can be in the form of parental advice to their children, advice about religion, expressions of love, and cremation or in the form of pampering lovers. This tradition is inseparable from the ideas, concepts, norms, and values that exist in the people of Lampung, who highly value politeness in conveying their intentions through poetry or rhymes in the form of a single in this gambus tunggal song.

To maintain this music's existence, Lampung traditional musicians collaborate with many institutions, such as Dewan Kesenian Lampung (DKL), Dewan Kesenian Lampung Selatan (DKLS), and tourism agencies. They still have concern for this art to maintain the existence by displaying this art when these institutions held events. Several times, a gambus tunggal player enters cultural galleries to teach this art. However, the enthusiasts are not as good as those who are interested in other Lampung traditional arts, such as tapis (traditional cloth from Lampung), or traditional dance from Lampung. This kind of art may be due to various things, including most people think that learning gambus tunggal are more complicated because they have to sing verses together. By playing the melody on the gambus, the performance is not as much as a dance performance or has an economic value such as a filter cloth with a reasonable selling price.

There are two kinds of techniques used in this gambus tunggal, namely humbak mulokh (waves that are going back to sea) for songs with a slower tempo with a nuance of profound sadness. Furthermore, ujan lijung technique (rain that stops slowly) used in songs to tell a person's feelings. The song from this gambus tunggal also functions as a dance accompaniment music. One of the dances that are characteristic of Lampung is the bedana dance. In this dance, a gambus tunggal has collaborated with a tambourine.

Gambus Tunggal Lampung players no longer feel awkward to accept technology. The influence of technology dramatically 
affects the existence of a gambus tunggal. Millennials are more interested in seeing shows on the internet, such as YouTube and Facebook. Gambus tunggal players are also affected by this new habit. Gambus tunggal players accept modernization by developing the show. They began recording videos, performing on various local radios, and uploading them on various digital platforms.

Although they do not yet know how to maximize digital platforms, identity awareness starts to emerge and gives rise to new digital communities. A gambus tunggal player starts to transform and starts to spread his knowledge through various video tutorials (Hidayatullah, 2019).

In Lampung, this local music is also called the petting gambus, and what distinguishes them from language, which poetry called segata. The instrument used was the guitar and gambus lunik. In the gambus balak (large) there are five pairs of strings and one pair that is not paired, all arranged into six notes in an open string, in the first pair or the lowest string is called kuin, the second genta, the third koro, the fourth tala, the fifth tuning tala tanggung, and the top is tala balak. Whereas the string arrangement in gambus lunik (small) only eliminates the two highest or lowest strings, namely the tala tanggung and the tala balak. The tuning on this gambus tunggal functions as a gong or bass. The fingerboard on this gambus is made fretless or without fret. So need a good tone sensitivity in playing it. In its development, petting lute, which is often used, is gambus lunik, due to getting a more comprehensive sound range.

The researchers agreed that gitar klasik Lampung and gambus Lampung became extinct (Barnawi, 2017; Hidayatullah, 2019; Irawan, 2013; Misthohizzaman, 2006; Tejapermana, 2014). However, previous studies have not yet discussed local artists and musicians' efforts to maintain their culture and music. Therefore, this study aims to discover the various elements that influence the existence of gambus tunggal player, and that encourages them to make an effort to survive.

\section{METHOD}

This study used qualitative research methods. Qualitative research produces descriptive data in the form of written or oral words from people and observed behavior (Moleong, 2017). Then Denzin \& Lincoln (2005) suggest that qualitative research is a study that uses a natural setting to interpret phenomena that occur and is carried out by involving a variety of existing methods. Studies are conducted to understand phenomena about what is experienced by research subjects such as behavior, perception, motivation, and actions. Holistically, and employing descriptions in the form of words and language, in a unique natural context, and by utilizing various scientific methods. Free interviews were conducted to collect primary data about a gambus tunggal artist's living conditions and the existence of his performances.

Furthermore, an observation was carried out to collect various gambus performance activities. The document study was carried out to collect various secondary information about cooperation agreements, Lampung government policies, and gambus tunggal music transcription. The research location is in Kalianda, South Lampung, and Kedondong Pesawaran Regency.

\section{RESULT AND DISCUSSION}

\section{Gambus Tunggal Lampung}

Gambus Tunggal is the result of acculturation from Arabic culture with Lampung culture because, in its history, this gambus tunggal music adopted the al-oud musical instrument from Arabic. (Kristianto, 2007), al-oud is a stringed instrument from Arabic, which is thought to be modern guitar instruments' ancestor. Historical records show that oud has been known since the 7th century, which is continually changing in shape and number of strings, it has no fret as known as fretless, and is picked using plectrum nor pick.

The Indonesian translation of the 
above statement is that al-oud is decorated with luxurious eastern ornaments and is the forerunner of all lutes that developed in Europe. The five paired strings are made of silk, but today the strings are made of nylon, which is connected along the length of the instrument's neck. Four of the paired strings are tuned for high to medium notes, while the fifth pair of strings are tuned for low notes. The tone in the $u d$ is vibrant. This kind of instrument makes it a well-known classical instrument in Arabic and a famous Eastern music ensemble.

Al-oud, which is the forerunner of the gambus, often also referred to the $u d$, which also developed in Europe. Lute is a stringed instrument like a guitar with a split pear shape, prevalent in Europe from the middle ages to the 18th century-a descendant of the musical instrument $u d$ in the middle east. Lute then changed into other stringed musical instruments, such as vihuela and guitar (Kristianto, 2007). The shape of the lute in Europ (on the resonator tube) is slightly smaller than the oud. The lute has a higher number of strings than the oud, and also, the lute uses a fret (limiting the tone region embedded in the instrument rod/string board, usually made of metal or animal bones). Here is a picture of a lute developing in Europe.

Irawan (2020) mention that originally the term of gambus was used to quote stringed musical instruments from the Middle East. It was changed to a format that began popular music with the term stringed orchestra. Finally, gambus is used to mention the type of Islamic music that contains dzikir and sholawat. Two types of gambus are commonly found in Lampung, namely standard-sized gambus as known as lute, and the small one called gambus lunik (see Figure 1).

Lute is also a descendant of oud in the Middle-East. This instrument is different from the musical instruments of Sumatera. These instruments originally entered this region are ouds; moreover, this area oud became better known as gambus. Gambus were getting more inclusion of music and musical instruments into the Lampung region-along with the influx of Islamic influence. The color of the music breathes Islamic while singing poetry. All of gambus players began in Arabic with accompaniment and poetry. In the Lampung region this artistry has various mentions, or terms, some refer to it as a gambus tunggal, a gitar tunggal, and some others call it a petting gambus.

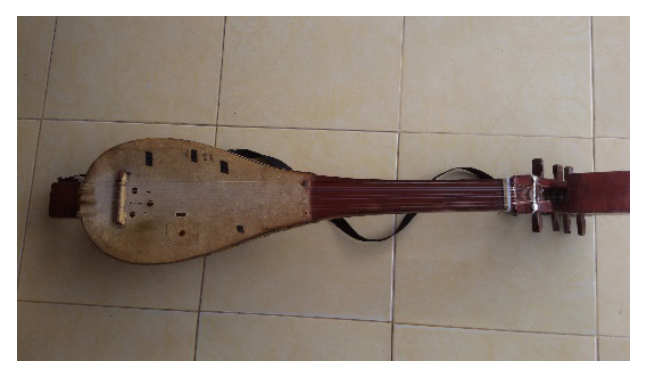

Figure 1. Gambus lunik (small)

(Source: personal document)

A gambus tunggal performance presents tunes adapted from the oud musical instruments, and are monophonic, meaning that they are not based on a contraption or harmony. While the scales used are the so-called maqam or maqamat, namely the arrangement of tones that are not tuned or tuned perfectly (well-tempered) like western music. However, when it is aligned with the scale of western music, this art refers to the harmonic minor scale and the minor scale byzantine scale. These scales are usually used in songs with Arabic or Middle Eastern nuances. If arranged in intervals of 1 octave on E tonality, the E minor harmonic scales will be arranged:

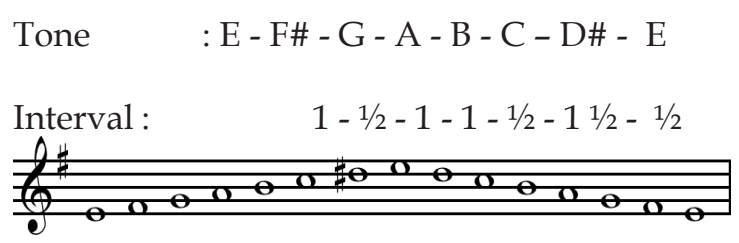

Figure 2. E minor harmonic scale (Source: personal document)

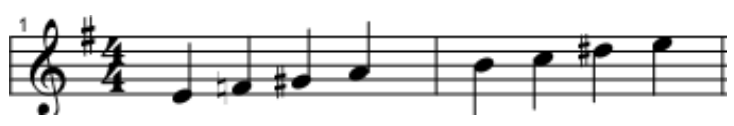

Figure 3. E byzantine scale

(Source: personal document) 
The gambus tunggal emphasizes the skill of playing a guitar melody that is played solo. Furthermore, this tool is used to sing the whole verse, which contains advice, expressions of love during ngiban (nganjang), as well as pampering a partner or spoiling a person (ngababang). Although single petting is an art that undergoes the process of acculturation from oud art from Arabic, the gambus tunggal is developed and adapted to the local traditions of the Lampung community. The following is an example of poet petting poetry related to God's exaltation, the relationship between man and his God, to remind people to always read Bissmillah (by saying the name of God) in every activity.

\author{
Bandung Satekhi \\ Pakhtamani bissmillah \\ Sina pai sai tibanca \\ Benoh kelawan salah \\ Tuhan juga nimbangnya \\ Sinji bandung satekhi \\ Pakaian didunia \\ Kantu kak sanak dukhi \\ Kham sayuk wingajahya \\ meaning:
}

The first is bismillah

That is the first time we read

True or False

Let God judge it

This (advice) is a piece of advice

For use in the world

For our future generations,

We must not be late teaching

The following is an example of a gambus tunggal poem in the form of a parent's advice to his son-in-law (the relationship between humans), to treat his husband well.

Pepok bilihmu mantu

Dang lamon pepikekhan

Ukhuskon do bakasmu

Sina sangun pilihan meaning

Take good care of Your self,

Your son-in-law

Do not think too much

Serve well Your husband

That has become a choice

(Rohaeli, personal communication,

March 20, 2013)

\section{The Exixtence of Gambus Tunggal}

Nowadays, gambus tunggal songs undergo many changes. A lot of classic pieces arranged, whether poetry and musical structure. The artists rarely write a musical transcript. Modern works are almost full of interpretations and adjust the mood of gambus players.

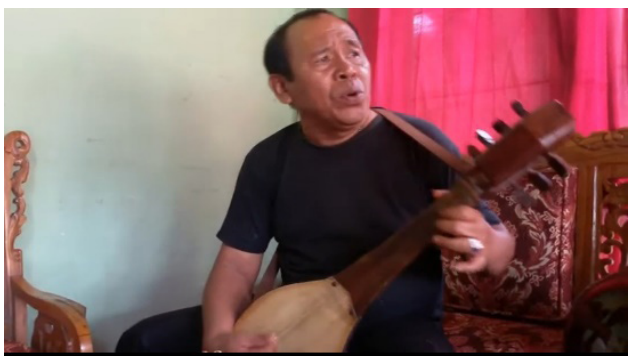

Figure 4. Humaidi plays gambus lunik (Source: personal document, 2017)

Humaidi, a gambus tunggal artist from Kedondong, Way lima, every gambus player, is free to interpret the songs performed as far as the song is still using the basic rules and techniques of gambus (see Figure4). A few years ago, stringed instruments and guitars were used as communal expressions that had a shared spirit. Besides being used in romance matters, a gambus tunggal serves as a reminder and advice. Older people have a responsibility to remind young people. This value is one of the identities of Lampung people who care about the younger generation.

\section{Strategies for Improving Collaboration}

The Lampung provincial government has a central role in developing a culture in the field of music. Gambus music players need to be united with various programs sourced from policies. Col- 
laboration is a real effort from the music community, government, and the private sector. Activities can be carried out on television, radio, digital platforms, and social media. Suprihatin and Pratamawati (2019) reported that the real efforts that can be done are the conservation of the performing arts. Collaboration between artists, the community, the government, and the potential of art (idea) can be developed (see Figure 5).

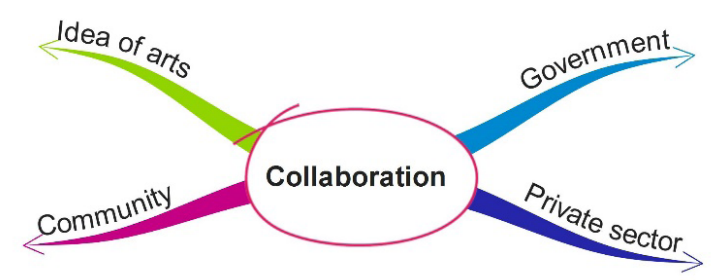

Figure 5. collaboration to maintain the existence

The majority of Lampung people are Muslim and very obedient. It is reflected in various arts and culture, including gambus tunggal music. Praises in the form of $d z i k i r$ and sholawat are sung and included in the lyrics and composition of music. Several other regions in Sumatera with a Malay cultural background also have this kind of Islamic music style.

The Lampung government created gitar klasik and gambus Lampung competition as part of the regency and Lampung Province anniversary. They showed up their skills in front of a jury from guitar and gambus musicians. Some young guitar players and gambus instruments emerged and formed a new ecology.

\section{CONCLUSIONS}

A gambus tunggal artist has made various efforts to maintain its existence in the societies to supporting communities. One of its efforts is to collaborate with related agencies so that there are concrete efforts made in terms of preserving the cultural products of the local community. In addition to collaborating with related agencies, Rohaeli (one of gambus activists) still actively plays a gambus tunggal instrument.
He also collaborates with a local television station, TVRI Lampung; hopefully, they expect that more people will see and know the arts by broadcast on television.

This study's results can be useful as a source of information, both for researchers, gambus tunggal artists, stakeholders, music education institutions, and the community, about the form of gambus tunggal, their development in the community. Researchers expect that the research results on the existence of a gambus tunggal can provide concrete benefits to the existence of traditional arts in society.

The tourism industry is the core of the sustainability of the Lampung music industry. The model of developing entrepreneurship training and tourism awareness is one solution (Nugraheni, et al., 2019). This model can be expanded within the local government structure and collaborate with researchers at universities and Lampung institutions.

\section{ACKNOWLEDGMENTS}

The author thanks all those who have helped research, the speakers, LPPM Lampung University, enumerators who assist in technical matters.

\section{REFERENCES}

Barnawi, E. (2017). Eksistensi gitar klasik Lampung tulang bawang dan pengembangannya. In N. Y. Ariyanti, E. S. Agustina, S. R. Sulistyanti, Hartoyo, E. Suroso, \& Sumaryo (Eds.), Prosiding kegiatan ilmiah tingkat nasional kearifan lokal dalam dinamika masyarakat multikultural (pp. 267-279). Bandar Lampung: LPPM Universitas Lampung.

Denzin, N. K., \& Lincoln, Y. S. (Eds.). (2005). The sage handbook of qualitative research (3rd ed.). United States of America: SAGE Publications, Inc.

Hadikusuma, H. (1990). Masyarakat dan adat budaya Lampung. Bandung: Mandar Maju.

Hidayatullah, R. (2019). Kelas daring: 
Metode pembelajaran Gitar Tunggal Lampung. In Viyanti, I. Rakhmawati, R. Anggreini, \& A. H. Saputri (Eds.), Prosiding Seminar Nasional Pendidikan Fakultas Keguruan dan Ilmu Pendidikan "Transformasi Pendidikan Abad 21 Мепијu Society 5.0" (pp. 606-613). Bandar Lampung: FKIP Unila.

Irawan, R. (2013). Deep structure pada peting gambus dan gitar Lampung Pesisir (Master Thesis). Pasca Sarjana Kajian Musik Nusantara, Institut Seni Indonesia Surakarta, Surakarta, Jawa Tengah.

Irawan, R. (2020). Terminologi gambus dalam spektrum musik di Indonesia. Journal of Music Science, Technology, and Industry, 3(1), 25-41.

Koentjaraningrat. (2009). Pengantar llmu antropologi (Revised). Jakarta: Rineka Cipta.

Kristianto, J. (2007). Gitarpedia: Buku pintar gitaris. Jakarta: Gramedia Pustaka Utama.

Misthohizzaman. (2006). Gitar klasik Lampung: Musik dan identitas masyarakat Tulang Bawang (Tesis). Universitas Gadjah Mada, Yogyakarta.
Moleong, L. J. (2017). Metodologi penelitian kualitatif (36th ed.). Bandung: PT. Remaja Rodakarya.

Nugraheni, T., Budiman, A., \& Sukmayadi, Y. (2019). Entrepreneurship and Art Education Tourism: A Study on Results of Management Skills Training Program for Students. Harmonia: Journal of Arts Research and Education, 19(2), 193-203.

Sinaga, R. M. (2012). (Re)produksi piil pesenggiri: Identitas etnis Lampung dalam hubungan dengan pendatang. Antropologi Indonesia, 33(2), 98-109.

Sumardjo, J. (2009). Filsafat seni (Vols 1-ITB Press). Bandung.

Suprihatin, E. W., \& Pratamawati, D. (2019). Conservation strategy in preserving the local image existence of Wayang Topeng. Harmonia: Journal of Arts Research and Education, 19(2), 179-184.

Tejapermana, P. (2014). Model pembelajaran petting tunggal untuk meningkatkan apresiasi musik peserta didik kelas xi di sman 1 sidomulyo Lampung Selatan (Tesis). Universitas Pendidikan Indonesia, Bandung. 